\title{
PENYULUHAN IMUNISASI DASAR ANAK PADA MASA ADAPTASI KEBIASAAN BARU
}

\author{
Hesteria Friska Armynia Subratha ${ }^{1}$ \\ ${ }^{1}$ Universitas Pendidikan Ganesha,
}

Corresponding author: Jalan Udayana No.11, Singaraja, 81116, Indonesia e-mail: hesteria.friska@yahoo.com

\section{Riwayat Artikel}

Diterima: 25 November 2021

Disetujui: 12 Desember 2021

Dipublikasi: 26 Desember 2021

\section{Keywords}

Immunization, adaptation, new

\begin{abstract}
The government has designated Coronavirus Disease 2019 (COVID-19) as a non-natural disaster in the form of an outbreak/pandemic, this determination is followed by efforts to prevent the spread of the corona virus through social restrictions, including restrictions on crowds, travel restrictions, implementation of isolation, delays and cancellations. events, as well as the closure of facilities and public service arrangements. This condition also affects the schedule and procedures for immunization services both at posyandu, puskesmas and other health facilities, including private ones). Nationally, Regency/City Immunization Coverage which reaches $80 \%$ of complete basic immunization is $37.2 \%$ of the target of $79.3 \%$ or the percentage of performance achievement is $46.9 \%$. Universal Child Immunization (UCI) Villages are villages where $80 \%$ of the total number of infants in the village have received complete basic immunization within one year. The coverage of UCI Villages/Urbans in Buleleng Regency, Bali Province in 2020 is 99.3\%, a decrease from 2019 which reached $100 \%$. Through this health education activity, it is expected to increase public knowledge about basic immunization for children during the adaptation period of new habits at the Posyandu, Kekeran Village, Busungbiu District, Buleleng Regency, Bali with various efforts in joint activities with all parties.
\end{abstract}

\section{PENDAHULUAN}

Imunisasi merupakan upaya yang paling efektif untuk memberikan kekebalan/imunitas spesifik terhadap Penyakit yang Dapat Dicegah Dengan Imunisasi (PD3I), sejarah telah mencatat bahwa semenjak ditemukannya vaksin, jutaan anak di seluruh dunia dapat diselamatkan dari kematian akibat PD3I, bahkan beberapa penyakit sudah berhasil dieradikasi dimuka bumi. Pemerintah telah menetapkan Coronavirus Disease 2019 (COVID19) sebagai bencana non-alam berupa wabah/pandemik, penetapan ini diikuti dengan upaya-upaya pencegahan penyebaran virus corona melalui pembatasan sosial antara lain pembatasan kerumunan orang, pembatasan perjalanan, pemberlakuan isolasi, penundaan dan pembatalan acara, serta penutupan fasilitas dan pengaturan pelayanan publik. Kondisi ini turut berpengaruh terhadap jadwal dan tata cara pelayanan imunisasi baik di posyandu, puskesmas maupun di fasilitas kesehatan lainnya termasuk swasta (Kemenkes RI, 2020).

Cakupan imunisasi rutin untuk mencegah penyakit-penyakit pada anak-anak seperti campak, rubella, dan difteri semakin menurun. Misalnya, angka cakupan imunisasi difteri, 
pertusis dan tetanus (DPT3) dan campak dan rubella (MR1) berkurang lebih dari 35\% pada bulan Mei 2020 dibandingkan periode waktu yang sama pada tahun sebelumnya (Kemenkes RI dan Unicef, 2020). Untuk lebih memahami efek pandemi COVID-19 terhadap imunisasi, Kementerian Kesehatan dan UNICEF melakukan penilaian cepat pada April 2020: hasilnya menunjukkan bahwa $84 \%$ dari semua fasilitas kesehatan (faskes) melaporkan layanan imunisasi terganggu di kedua level yaitu Puskesmas dan Posyandu (Kemenkes RI dan Unicef, 2020).

Secara Nasional pada tahun 2020, cakupan Imunisasi Kabupaten/Kota yang mencapai 80\% imunisasi dasar lengkap tercapai $37,2 \%$ dari target $79,3 \%$ atau persentase pencapaian kinerja sebesar 46,9\% (Kemenkes RI, 2021). Desa/Kelurahan Universal Child Immunization (UCI) adalah desa/kel dimana $\geq 80 \%$ dari jumlah bayi yang ada di desa tersebut sudah mendapat imunisasi dasar lengkap dalam waktu satu tahun. Cakupan Desa/Kelurahan UCI di Kabupaten Buleleng Provisi Bali tahun 2020 adalah sebesar 99,3\% menurun dari tahun 2019 yang mencapai 100\% (Dinas Kesehatan Kabupaten Buleleng, 2021).

Hail wawancara dengan orang tua balita di wilayah kerja Puskesmas Busungbiu I menunjukkan bahwa sejumlah orang tua khawatir untuk memberikan imunisasi bagi anaknya, dan tidak sedikit pula petugas kesehatan ragu-ragu dalam menyelenggarakan pelayanan imunisasi di tengah pandemi COVID-19. Jika kondisi ini terus dibiarkan, maka cakupan imunisasi nasional akan turun, sehingga kekebalan komunitas tidak terbentuk lagi dan pada akhirnya cakupan imunisasi yang rendah ini bisa menyebabkan terjadinya KLB PD3I seperti Campak, Rubela, Difteri, Polio dan lainnya. Tentunya ini akan menjadi beban ganda bagi masyarakat dan negara di tengah pandemi COVID-19 yang masih berlangsung (Kemenkes RI, 2020). Hal ini menjadi menjadi salah satu pertimbangan pemilihan lokasi pengabdian masyarakat. Kegiatan penyuluhan dijadikan sebagai salah satu alternatif kegiatan sesuai dengan upaya solusi penyelesaian masalah sosial berupa dengan melakukan penyuluhan kesehatan sebagaimana konsep yang disampaikan oleh Rufaidah Al Aslamiyah yang menganjurkan perawatan pencegahan dan megakui pentingnya Pendidikan kesehatan (Risnah \& Muhammad Irwan, 2021). Melalui kegiatan penyuluhan kesehatan ini diharapkan meningkatkan pengetahuan masyarakat tentang imunisasi dasar anak pada masa adaptasi kebiasaan baru di Posyandu Desa Kekeran Kecamatan Busungbiu Kabupaten Buleleng Bali dengan berbagai upaya dalam kegiatan bersama semua pihak.

\section{METODE}

Kegiatan pengabdian dilakukan dalam bentuk penyuluhan kesehatan pada masyarakat di Posyandu Desa Kekeran Kecamatan Busungbiu Kabupaten Buleleng. Kegiatan penyuluhan tentang pentingnya imunisasi dasar dimasa pandemi Covid 19 ini dilaksanakan pada hari Rabu tanggal 13 Oktober 2021 di Posyandu Desa Kekeran Kecamatan Busungbiu Kabupaten Buleleng Bali. Penyuluhan ini dihadiri oleh ibu-ibu yang mempunyai bayi dan balita yang berada di Desa Kekeran Kecamatan Busungbiu Kabupaten Buleleng. Materi yang diberikan adalah pengertian imunisasi, manfaat imunisasi, jenis-jenis imunisasi dan jadwal imunisasi.

Alat bantu yang digunakan dalam rangakaian kegiatan ini berupa sound system, flipchart serta seminar kit yang diberikan kepada tiap peserta yang hadir. Peserta yang hadir dalam kegiatan penyuluhan ini adalah orang tua dan pengasuh Balita yang mendapatkan Imunisasi Dasar. Adapun metode yang dipergunakan berupa rangkaian kegiatan dengan langkahlangkah persiapan penyuluhan yang diawali dengan menyusun jadwal pelaksanaan penyuluhan berupa hari, tanggal, dan tempat lalu menentukan tema/topik bahasan yang tepat untuk materi penyuluhan. Selanjutnya menentukan tim panitia, Narasumber dan moderator sasaran.

\section{HASIL DAN PEMBAHASAN}

Imunisasi berasal dari kata imun, kebal atau resisten. Anak diimunisasi, berarti diberikan kekebalan terhadap suatu penyakit tertentu. Anak kebal atau resisten terhadap suatu 
penyakit tetapi belum tentu kebal terhadap penyakit yang lain. Imunisasi adalah suatu upaya untuk menimbulkan/meningkatkan kekebalan seseorang secara aktif terhadap suatu penyakit, sehingga apabila suatu saat terpajan dengan penyakit tersebut tidak akan sakit atau hanya mengalami sakit ringan (Kementerian Kesehatan Republik Indonesia, 2015). Imunisasi merupakan salah satu cara yang efektif untuk mencegah penularan penyakit dan upaya menurunkan angka kesakitan dan kematian pada bayi dan balita (Mardianti \& Farida, 2020). Imunisasi merupakan upaya kesehatan masyarakat paling efektif dan efisien dalam mencegah beberapa penyakit berbahaya (Kementerian Kesehatan Republik Indonesia, 2020). Imunisasi merupakan upaya pencegahan primer yang efektif untuk mencegah terjadinya penyakit infeksi yang dapat dicegah dengan imunisasi (Senewe et al., 2017).

Tujuan imunisasi adalah agar memdapatkan imunitas atau kekebalan anak secara individu dan eradikasi atau pembasmian sesuatu penyakit dari penduduk sesuatu daerah atau negeri. Sedikitnya $70 \%$ dari penduduk suatu daerah atau negeri harus mendapatkan imunisasi. Yang tidak kalah pentingnya adalah imunisasi ulang (booster) yang perlu dilaksanakan dalam waktu-waktu tertentu untuk meningkatkan kembali imunitas/kekebalan penduduk (Kemenkes RI, 2016).

Berikut jenis-jenis imunisasi yang diwajibkan oleh pemerintah dan bisa didapat secara gratis di Puskesmas atau Posyandu:

Tabel 1. Jenis Imunisasi Dasar di Posyandu

\begin{tabular}{|c|c|}
\hline Jenis Vaksin & Keterangan \\
\hline$B C G$ & 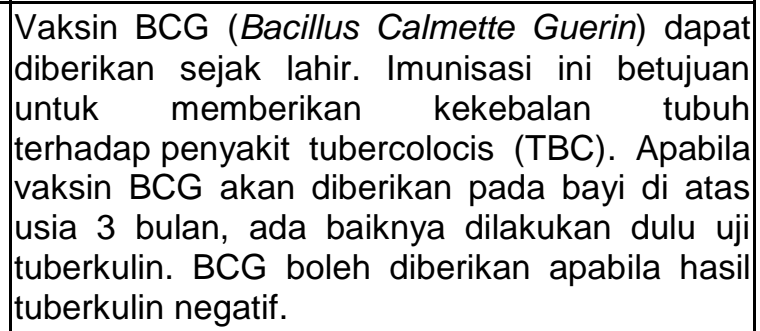 \\
\hline Hepatitis B & $\begin{array}{l}\text { Vaksin Hepatitis B yang pertama harus } \\
\text { diberikan dalam waktu } 12 \text { jam setelah bayi } \\
\text { lahir, kemudian dilanjutkan pada umur } 1 \text { bulan } \\
\text { dan } 3 \text { hingga } 6 \text { bulan. Jarak antara dua } \\
\text { imunisasi Hepatitis B minimal } 4 \text { minggu. } \\
\text { Imunisasi ini untuk mencegah penyakit } \\
\text { Hepatitis B. }\end{array}$ \\
\hline Polio & $\begin{array}{l}\text { Imunisasi Polio diberikan untuk mencegah } \\
\text { poliomielitis yang bisa menyebabkan } \\
\text { kelumpuhan. }\end{array}$ \\
\hline DPT & $\begin{array}{l}\text { Vaksin DPT adalah vaksin kombinasi untuk } \\
\text { mencegah penyakit difteri, pertusis (batuk } \\
\text { rejan), dan tetanus. Ketiga penyakit ini sangat } \\
\text { mudah menyerang bayi dan anak. Imunisasi } \\
\text { DPT diberikan pada bayi umur lebih dari } 6 \\
\text { minggu. Vaksin DPT dapat diberikan secara } \\
\text { simultan (bersamaan) dengan vaksin Hepatits } \\
\text { B. Ulangan DPT diberikan pada usia } 18 \text { bulan } \\
\text { dan } 5 \text { tahun. Usia } 12 \text { tahun mendapat vaksin } \\
\text { TT (tetanus) melalui program Bulan Imunisasi } \\
\text { Anak Sekolah (BIAS). }\end{array}$ \\
\hline Campak & $\begin{array}{l}\text { Vaksin Campak-1 diberikan pada usia } 9 \text { bulan, } \\
\text { lalu Campak-2 pada usia } 6 \text { tahun melalui } \\
\text { program BIAS. }\end{array}$ \\
\hline
\end{tabular}


Beberapa prinsip yang menjadi acuan dalam melaksanakan program imunisasi pada masa pandemi COVID-19 yaitu: 1) imunisasi dasar dan lanjutan tetap diupayakan lengkap dan dilaksanakan sesuai jadwal untuk melindungi anak dari PD3I; 2) secara operasional, pelayanan imunisasi baik di posyandu, puskesmas, puskesmas keliling maupun fasilitas kesehatan lainnya yang memberikan layanan imunisasi mengikuti kebijakan pemerintah daerah setempat; 3) kegiatan surveilans PD3I harus dioptimalkan termasuk pelaporannya; serta 4) menerapkan prinsip PPI dan menjaga jarak aman 1 - 2 meter (Kemenkes RI, 2020).

Menurut Notoatmodjo 2012 bahwa pendidikan sangat erat kaitannya dengan pengetahuan. Sehingga semakin tinggi pendidikan seseorang, maka akan semakin mudah untuk menerima serta mengembangkan pengetahuan termasuk pengetahuan. Hal ini sesuai dengan tujuan pendidikan kesehatan adalah untuk mengubah pengetahuan, mengubah sikap dan persepsi serta menanamkan perilaku yang baru. Pengetahuan bukan sesuatu sifatnya berhenti akan tetapi memerlukan proses untuk memperolehnya. Pengetahuan adalah sesuatu pembentukan yang terus menerus oleh seseorang yang setiap saat mengalami reorganisasi karena adanya pemahaman-pemahaman baru. Pengetahuan dalam pandangan konstruktivistis bukanlah fakta dari suatu kenyataan yang sedang dipelajari, melainkan sebagai konstruksi kognitif seseorang terhadap obyek, pengalaman, maupun lingkungannya. Perilaku seseorang cenderung menjadi baik bila pengetahuannya juga tinggi (Notoatmodjo, 2012).

Pendidikan kesehatan sangat berkorelasi dengan pengetahuan dan pemahaman kesehatan yang memadai (Chen et al., 2014). Selama proses penyampaian materi, peserta mendengarkan dengan baik. Peserta juga diberikan kesempatan untuk bertanya mengenai topik yang dibahas. Diakhir kegiatan, tim pengabdi melakukan sesi tanya jawab dengan peserta. Setelah kegiatan dilakukan, dapat diketahui bahwa terjadi penambahan ilmu pengetahuan peserta khususnya mengenai imuniasi dasar. Hal ini dilihat dari pertanyaanpertanyaan dari tim pengabdi yang berhasil dijawab oleh peserta di akhir kegiatan.

\section{KESIMPULAN}

Dari hasil pengabdian yang dilakukan pengabdi maka dapat disimpulkan bahwa penyuluhan kesehatan berpengaruh terhadap perubahan pengetahuan ibu mengenai pentingnya imunisasi dasar pada masa adaptasi kebiasaan baru di Desa Kekeran Kecamatan Busungbiu Kabupaten Buleleng.

\section{UCAPAN TERIMA KASIH}

Ucapan terimakasih kami sampaikan kepada Pihak Posyandu Desa Kekeran Kecamatan Busungbiu Kabupaten Buleleng, dan Puskesmas Busungbiu I yang telah mendukung kegiatan Penyuluhan Kesehatan dalam upaya peningkatan pengetahuan masyarakat tentang pentingnya imunisasi dasar pada masa adaptasi kebiasaan baru dalam program pengabdian masyarakat sebagai bagian dari Tri dharma perguruan tinggi.

\section{DAFTAR REFERENSI}

Dinas Kesehatan Kabupaten Buleleng. (2021). Profil Kesehatan Buleleng Tahun 2020. Pemerintah Kabupaten Buleleng. Singaraja.

Direktorat Promosi Kesehatan dan Pemberdayaan Masyarakat. (2016). Pentingnya Imunisasi. Kementerian Kesehatan. Avaible at: https://promkes.kemkes.go.id/?p=5422

Kementerian Kesehatan Republik Indonesia. 2015. Buku ajar imuniasi. Kementerian Kesehatan RI. Jakarta

Kemenkes RI. (2020). Petujuk Teknis Pelayanan Imunisasi Pada Masa Pandemi Covid-19. Kementerian Kesehatan. Jakarta

Kemenkes RI dan UNICEF. (2020). Imunisasi Rutin pada Anak Selama Pandemi Covid-19 di Indonesia: Persepsi Orang tua dan Pengasuh. Kementerian Kesehatan. Jakarta 
Kemenkes RI. (2021). Laporan Kinerja Kementerian Kesehatan Tahun 2020. Kementerian Kesehatan. Jakarta

Mardianti, M., \& Farida, Y. 2020. Faktor - Faktor Yang Berhubungan Dengan Status Imunisasi Dasar Pada Bayi Di Desa Rengasdengklok Selatan Kabupaten Karawang. Jurnal Kebidanan Indonesia: Journal of Indonesia Midwifery, 11(1), 17. https://doi.org/10.36419/jkebin.v11i1.322

Notoatmodjo, Soekidjo. 2012. Pendidikan dan perilaku kesehatan. Jakarta: Rineka Cipta

Risnah dan Muhammad Irwan, 2021, Falsafah dan teori keperawatan dalam integrasi keilmuan, Alauddin university press.

Senewe, M., Rompas, S., \& Lolong, J. 2017. Analisis Faktor-Faktor Yang Berhubungan Dengan Kepatuhan Ibu Dalam Pemberian Imunisasi Dasar Di Puskesmas Tongkaina Kecamatan Bunaken Kota Madya Manado. Jurnal Keperawatan UNSRAT, 5(1), 109743. 